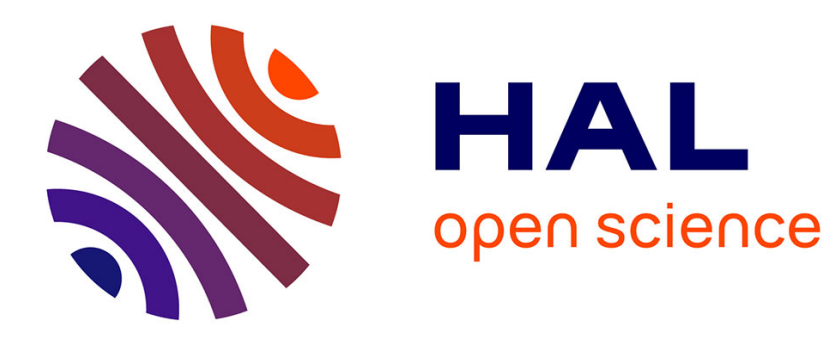

\title{
Ramadan during a Civil War (as reflected in a series of sermons)
}

Xavier Bougarel

\section{To cite this version:}

Xavier Bougarel. Ramadan during a Civil War (as reflected in a series of sermons). Islam and Christian-Muslim Relations, 1995, VI (1), pp.79-103. halshs-00300724

\section{HAL Id: halshs-00300724 https://shs.hal.science/halshs-00300724}

Submitted on 18 Jul 2008

HAL is a multi-disciplinary open access archive for the deposit and dissemination of scientific research documents, whether they are published or not. The documents may come from teaching and research institutions in France or abroad, or from public or private research centers.
L'archive ouverte pluridisciplinaire $\mathbf{H A L}$, est destinée au dépôt et à la diffusion de documents scientifiques de niveau recherche, publiés ou non, émanant des établissements d'enseignement et de recherche français ou étrangers, des laboratoires publics ou privés. 


\title{
« Ramadān during a Civil War (as reflected in a series of sermons)", Islam and Christian-Muslim Relations, vol. VI, $\mathrm{n}^{\circ} 1,1995$, pp. 79-103.
}

\author{
Xavier Bougarel
}

\author{
Our goal: the islamization of Muslims
}

Our slogan: believe and fight.

\section{(A. Izetbegović, Islamic Declaration, 1970)}

There can be few Muslims for whom the 1992 Ramadān will have been as crucial as it was for the 1,900,000 Muslims of Bosnia-Herzegovina, ${ }^{1}$ caught as they were in the torment of the Yugoslav crisis. From 5 to 30 March, the month of Ramadān was preceded and followed in Bosnia-Herzegovina by two events of the utmost importance for Bosnian Muslims, and for their political and national future.

On the 29 February and 1 March the referendum on the future of this Yugoslav republic took place. Initiated by the Party of Democratic Action (SDA), ${ }^{2}$ it was supported by the majority of Bosnian political parties, as well as by the Catholic and Muslim religious hierarchies. All together $62,7 \%$ of the registered electors voted in favour of independence, in spite of the furious opposition of the Serb Democratic Party (SDS). ${ }^{3}$

Acting on the outcome of this referendum, the European Community, followed by the United States, decided to recognize the independence of Bosnia-Herzegovina on 6 April, i.e. on the third day of the ramazanski bajram, marking the end of the fast of Ramadān.

At the same time, this month of Ramadān was marked by the brutal transition from a miraculously preserved state of peace to a state of open and murderous civil war. Under the aegis of the European Community, negotiations over the future of Bosnia-

\footnotetext{
1 The Muslims were recognized as a nation in 1971 and became the sixth constituent nation of Yugoslavia. They are the descendants of Slavs islamized during the five centuries of the Ottoman presence in the Balkans. At the last census in 1991 they numbered 2,400,000 in Yugoslavia, of whom $1,900,000$ were in Bosnia-Herzegovina and 240,000 in Serbia, principally in the Sandžak region (Novi Pazar). Muslims in the confessional sense are estimated to number approximately $6,000,000$ in Yugoslavia, and are made up of several national groups (Muslims, Albanians, Turks, Macedonians) and/or ethnic groups (Gypsies, Torbeshs, Goranis, etc.).

${ }^{2}$ Created in March 1990, the Party of Democratic Action (Stranka demokratske akcije - SDA) has attracted the majority of Muslim votes and has thus become the principal party in Bosnia-Herzegovina since the first free elections in that republic in December 1990. Its president, Alija Izetbegović, then became president of the collective presidency of Bosnia-Herzegovina.

${ }^{3}$ The composition of the Bosnia-Herzegovina population is as follows: Muslims $43,7 \%(1,906,000)$, Serbs $31,3 \%(1,370,000)$, Croats $17,3 \%(756,000)$, Yugoslavs and others $7,7 \%(334,000)$. The votes of the Serb and Croat communities went overwhelmingly in December 1990 to the candidates of their respective national parties, the Serb Democratic Party (Srpska demokratska stranka - SDS) and the Croat Democratic Community (Hrvatska demokratska zajednica - HDZ). Following the elections a coalition government was formed of the three national parties (SDA, SDS, HDZ). This coalition held until the outbreak of civil war, in spite of the conflicts which riddled it form the start, its growing paralysis and its increasingly obvious absurdity.
} 
Herzegovina have led to a complete deadlock in the Bosnian institutional and political system, in spite of, or rather because of, the signing of two agreements, which were soon given the lie by events, and then disowned by their actual signatories. Each of the agreements, the first signed in Lisbon on 22 February, and the second signed in Sarajevo on 18 March, provided for an independent Bosnia-Herzegovina, within its present frontiers, and the recognition within this state, described as secular, of three 'constituent entities' on territories defined by the criteria of ethnic majorities. In each case it took only a few days for one or other of the national parties which were signatories to contest the terms of the agreement. The reality of the actual political situation thus finally demonstrated the futility of a compromise extorted from partners who were unconcerned about keeping their word.

On the day after the referendum, the appearance of Serb barricades around Sarajevo had shown that, given a situation of extreme inter-ethnic tension, there was a risk that force would become the only argument to carry any weight in the Bosnian political game. Removed in Sarajevo on 4 March, the barricades spread throughout the whole of Bosnia-Herzegovina, and led to increasingly violent confrontations, in Bosanski Brod (4 March), in Mostar and the whole of the Neretva valley (9 March), in Ljubinje and Goražde (22 March), in Derventa (26 March), in Doboj, Kupres, in the Drina valley, etc. Having left Sarajevo in peace for a while, violence erupted there again on 5 April, the day on which a civil war, chaotic in nature and whose outcome remains uncertain, broke out in the Bosnian capital.

In a republic where confessional differences correspond to ethnic differences, and where the political game is entangled with inter-ethnic clashes, we must look at the relations between religion and politics within this republic, and especially among Muslims. From this point of view, the month of Ramadān seems especially appropriate. The organization of Ramadān and the way it proceeds, the comments of the Islamic press, and finally the contents of the sermons given in the various mosques of Sarajevo, ${ }^{4}$ enable us to get a far better idea of the pluralist reality of Bosnian Islam, than do the speeches which present a caricature of 'Bosnia, Islamic republic', or 'Islam, religion of peace and tolerance'. What form does Islamic renewal take in Bosnia-Herzegovina, and what difficulties does it face? Is there only one or are there several plans for the re-Islamization of the Muslim community? Is Islam

\footnotetext{
${ }^{4}$ We refer to the following sermons:

21 March, Tabački mesdžid (mukabela): Jusuf Ramić, Rector of the Faculty of Islamic Theology (ITF). 22 March, Tabački mesdžid (mukabela): Mehmedalija Hadžić, professor at the ITF, responsible for religious issues in the editorial board of Muslimanski glas and secretary of the el-Hidaje association. 23 March, Baščaršijska džamija (vaz): Ismet Spahić, imām of the Begova džamija (the main mosque in Sarajevo).

23 March, Tabački mesdžid (mukabela): Hussein Smajić, principal imām of Sarajevo.

24 March, Čekrekčina džamija (vaz): Mesud Hafizović, professor at the ITF.

24 March, Tabački mesdžid (mukabela): Enes Karić, professor at the ITF, member of editorial board of Muslimanski glas.

25 March, Č́obanija džamija (vaz): Mustafa Spahić, imām, member of the editorial board of Muslimanski glas.

25 March, Tabački mesdžid (mukabela): Džemaludin Latić, editor-in-chief of Muslimanski glas.

26 March, Ali-pašina džamija (vaz): Ferid Dautović, imām of the Ferhadija džamija.

26 March, Tabački mesdžid (mukabela): Muhamed Porča, imām in the town of Visoko (30 km northeast of Sarajevo).

22 and 27 March, Ferhadija džamija (mukabela): Mehmedalija Hadžić.
} 
characterized by moderation or by mobilization in the crisis of inter-ethnic relations? Is Bosnian Islam, an Islam on the periphery, in tune with the rest of the Islamic world? These are the questions to which we will try to find answers.

\section{The Organization and Progress of Ramadān in Bosnia-Herzegovina}

According to a survey conducted in all the Yugoslav republics in $1990,{ }^{5}$ the level of religious observance among the Muslims was among the lowest of all the Yugoslav nations: $37 \%$ of them claimed to be religious, compared with $70 \%$ of the Albanians, $60 \%$ of the Slovenes, $53 \%$ of the Croats, $45 \%$ of the Macedonians, $35 \%$ of the Montenegrins and $34 \%$ of the Serbs. Another survey, conducted in the same year by D. Pantić, ${ }^{6}$ showed that only $34 \%$ of the young Muslims living in Bosnia-Herzegovina regarded themselves as religious, $56 \%$ as non-religious and $10 \%$ as indifferent or uncertain. Among these young people, 61\% stated that they never attended the mosque.

Against this background, it is easy to understand that the collapse of communism and the accompanying increase in religious observance represent for the religious leaders of Bosnia-Herzegovina both an opportunity and a challenge. Having been long subject to the supervision of the political authorities, the Islamska zajednica ${ }^{7}$ saw the beginnings of the process of democratization as a liberation. But this democratization shook the Islamic religious structures more than those of other groups. We can see this, especially in Bosnia-Herzegovina, from the way in which some religious leaders compromised with the 'ancient régime' were dismissed, and from the outbreak of recurrent disputes inside Islamska zajednica, as well as between this structure and certain representatives of the SDA.

Ramadān is thus looked forward to as a special opportunity for re-affirming a religious identity, regarded as inseparable from national identity, and for calling Muslims to return to their traditions and faith. In the words of Preporod ('Renaissance'), the organ of the Islamska zajednica of Bosnia-Herzegovina, Ramadān is 'the unifying force of Muslims'; for Muslimanski glas ('The Muslim Voice'), the SDA's weekly publication, it is 'the greatest school of life'. Muallim ('The Teacher'), the organ of the Association of 'ulamās (religious scholars) of Bosnia-Herzegovina, reminds its readers that Ramadān is 'the month of the Qur'ān':

the Muslim has a duty to open the pages of this Qur'ān, and to learn and welcome its sublime messages. He will think about the umma to which he belongs, he will involve himself in its affairs, and make his valuable contribution to solving any problems which exist, and to eliminating its imperfections. He will think of himself and his family as a basic cell of this society, for which he is responsible.

\footnotetext{
${ }^{5}$ D. Pantić, « Religioznost gradana Jugoslavije », in: Institut društvenih nauka, Jugoslavija na kriznoj prekretnici (Belgrade, 1991).

${ }^{6}$ D. Pantić, " Prostorne, vremenske i socijalne koordinate religioznosti mladih u Jugoslaviji », in: Institut društvenih nauka, Deca krize: omladina Jugoslavije krajem osamdesetih (Belgrade, 1990).

7 The Islamska zajednica groups and organizes all the Muslims in Yugoslavia, whatever their nationality. It is divided into five administrative regions (Bosnia-Herzegovina, Kosovo-SerbiaVojvodina, Macedonia, Montenegro, Croatia-Slovenia).
} 
However, if reading the Qur'ān by oneself remains one of the duties of a believer, the Islamska zajednica lays great stress on organizing mukabelas, the reading and interpretation of the Qur'ān by an 'âlim (religious scholar) to a group of the faithful. On this subject Preporod of 15 March had this to say: 'Side by side with intensive study of the Qur'ān by individuals within the family circle', this method of coming face to face with the Qur'ān 'as an act of collective devotion to the Qur'ān on the part of those Muslims living in a particular region, leaves visible marks on the individual'. All collective activities linked to the month of Ramadān should thus contribute towards re-affirming a collective religious identity, and consequently, to the renewal or awakening of individual faith. This applies not only to daily prayers, sermons and mukabelas, but also to iftārs, the evening meal which marks the end of the fast. According to Muslimanski glas of 6 March, 'preparing the iftār encourages sociability, reconciliation, getting to know people, association, mutual adaptation and solidarity among Muslims'. In the same spirit, Preporod asks the associations MOS, Preporod and Merhamet ${ }^{8}$ to 'organize as many public iftārs as possible in those places provided for this purpose'.

In general, and in the absence of any statistics on this matter, it does seem that the Ramadān fast and the activities associated with it have been observed to a far greater extent this year than in previous years. However, this growth in religious observance, while representing a success for the Islamska zajednica, only makes the gaps in is staffing and organization more obvious. On 15 March Preporod reported for example that this year in Sarajevo there were ten additional places of prayer for performing the teravija (the evening prayer during the period of Ramadān), but that in the whole of Bosnia-Herzegovina, because of the lack of staff and because of the political situation, some 150 jamā'ats (communities of the faithful, praying in the same mosque) had nobody qualified to perform the teravija.

In the course of various seminars which brought together between 17 February and 2 March the imāms from several regions of Bosnia-Herzegovina to prepare for Ramadān, even the Islamska zajednica admitted its shortcomings. Preporod stated in its report of 1 March that:

a considerable number of imāms and mu'allims [teachers] are incapable of responding to the needs of a new dynamic and to a level of activity that one has the right to expect in a period of rapid growth in those areas in which Islamska zajednica is active. Some of them quite simply lack recent training; others are not aware that a wider engagement and greater degree of enthusiasm are needed for the new activities involved in the work of an imām. We must not lose sight of the fact that this situation is largely the result of ways of working inherited from the communist era, as well as the lack of adaptation and the weakness of our system of education within the Islamska zajednica.

These weaknesses in the Islamska zajednica's system of training have led not only to poor organization in some of its activities, but also to their being taken over by certain oppositional structures or by others which are not strictly religious in character.

\footnotetext{
${ }^{8}$ The Muslim Youth Organization (Muslimanski omladinski savez - MOS), the cultural organization Preporod (Renaissance) and the charitable organization Merhamet (Charity) were created or reconstituted in 1990 . They are generally closely linked with the SDA and the Islamska zajednica.
} 
During the Ramadān, and in the city of Sarajevo at least, one of the most active circles has undoubtedly been the el-Hidaje ('The Right Path') association of 'ulamās. This organization, formed in September 1991, brings together those who are opposed to the policies of the 'official' Association of 'ulamās of Bosnia-Herzegovina and those of Salih Člaković, the present President of the Islamska zadjenica in BosniaHerzegovina. It seems to have the support of at least some of the leaders of the SDA. Was Salih Čolaković thinking of el-Hidaje or organizations like Preporod and Merhamet, when he wrote in Preporod on the subject of collecting zakāt and sadaqat al-fitr (the ritual taxes collected during Ramadān):

More than twenty years ago our 'ulamās delivered a fatwā [a legal decision] according to which the collection and distribution of the zakät is the exclusive prerogative of the Islamska zajednica. (...) Nowadays, without a fatwo and without consulting anybody, certain people have taken the right to say that somebody other than the Islamska zajednica can collect the zakät and the sadaqat al-fitr, that they can arrange the distribution for purposes other than those to which we have agreed as Muslims?

However, it is not internal conflicts that have marked this Ramadān, so much as the outbreak of armed inter-ethnic conflicts. In Sarajevo, as well as in many other places, prayers have been conducted under the protection of members of Muslim paramilitary units, popularly known as 'green berets'. For the first time in the history of Islam in Bosnia, on 30 March 1992, the night of laylat al-qadr (the $26^{\text {th }}$ day of Ramadān, the anniversary of the beginning of the revelation of the Qur'ān) was celebrated to the sound of automatic fire. More seriously, this Ramadān was marked by an increased number of assassinations and attacks on places of Muslim worship by reservists of the federal army or by groups of Serb terrorists. According to the Muslim press agency MINA, during the month of March, thirteen Muslim places of worship, mosques or mesdžids (prayer rooms), were objects of armed attack.

These various attacks on places of worship have rightly been perceived as an attack on Islam in general, and, in the course of Ramadān, as an attempt to prevent Muslims from re-affirming their faith. Reacting to the machine-gunning of the Gnojnice mosque by reservists of the Federal army, the chief imām of Mostar, Šfik Tinjak, wrote in his message of 25 March that 'every sounding of the adhān [the call to prayer] from the top of the mosque's minaret provokes fury and hatred among the reservists stationed on the surrounding heights, feelings which they relieve by bursts of fire', and he sees in this a desire, 'to threaten and frighten the faithful so that they no longer visit the mosque, constituting a return to the well-known scenario of aggression, nationalistic chauvinism, and long-term intolerance towards everything that is Islamic or Muslim, and thus towards Muslims themselves'.

The worsening of the political situation before and during Ramadān is reflected in the Muslim press by a growing insistence on the importance of Islam during a time of crisis. Far from turning Muslims away from their faith, the dangers of civil war should, on the contrary, encourage them even more to return to their faith, because, as M. Hadžić wrote in Muslimanski glas on 13 March, 'today, when we are facing great challenges and trials, on whose outcome our whole future in this region depends, fasting will teach us the necessary patience, will accustom us to carrying out the most difficult obligations, and will discipline us'. 
Affirming the importance of Islam in a time of crisis is not to prejudge the functions which it is expected to fulfil at such times. In particular, references to Islam can be included in policies of moderation (appeal being made to $s a b r-$ i.e. patience and endurance under adversity), just as in strategies of mobilization (being expressed in a call to jiha $\bar{a}$, in the form of a holy war). On the occasion of the opening ceremony of the ramazanski bajram on 4 April at Pljevlja in Montenegro, the Reisu-l-ulema, Jakub ef. Selimoski, declared himself against any use of Islam for purposes of mobilization, stating:

We will never tolerate, and we should never tolerate, people and nations hating each other, falling out with each other and fighting in the name of faith. On the contrary, we never cease calling upon people, in the name of the one and only God who is the Creator of the world, to live in peace. (...) The Qur'ān has taught us from the outset that, if anyone kills a single man unjustly, it is as if he had killed the whole world, and that if anyone saves the life of a single man, it is as if he had saved the whole world. This is Islamic humanism, its humanity, its divine foundation. Allāh is the judge of life and death, and of history. That is why we call from this place upon all those who may hear this call to stop the war and the murders, the humiliation and harassment, every kind of violence, everything that causes fear and insecurity. May hatred and suspicion cease, may men return to God and to themselves, and may they open the doors of dialogue, of fair words and model behaviour.

For Jakub ef. Selimoski the month of Ramadān is the month when 'all the essential events in our history had their beginnings or reached their climax. We come out of Ramadān stronger and more reflective, calmer and more devout, with fresh knowledge, closer to God, and so closer to the man within us and the man who stands beside us'. At the end of Ramadān, 'the joy of the bajram is not the joy of the individual, but that of the believing people'. He goes on to say that his joy

should not be affected by the fact that we have been confronted during this blessed month of Ramadān by those who sow disorder and confusion on earth, and who have attacked our faith, our lives and our honour. (...) We have not responded to them. We are a nation enhanced, strengthened and made exemplary by suffering and sabr. We understand this as being tested by Allāh, for He has said that He will put us to the test through fear, hunger and crime and our faith in Him is confirmed, we remain upright and worthy.

Does this reflect different ways of understanding, or different roles to be performed? In the Islamic press the understanding of the ideas of $s a b r$ and of jihäd remains much more ambiguous. Muallim, the organ of the Association of ulamās of BosniaHerzegovina, describes the month of Ramadān as: 'the month of jihād, for forgiveness and tolerance'. In general, it seems that the idea of $s a b r$, defined as active behaviour and not purely in a passive sense, and the idea of jihäd, defined as internal struggle as much as holy war, are of equal importance, and are complementary rather than opposites. At the same time, the permanent call not to respond to provocation is far from ruling out the need for military preparations. If words have no effect, warns Muallim, 'Ramadān is the month of jihād, and the believer must defend himself'. 
Against this background, the commemoration of the Battle of Badr (held on the $17^{\text {th }}$ day of Ramadān, on the 21 March this year), has a very special significance. The Prophet's military victory over an ennemy who had the advantage in numbers, in the second year after the Hijra, is reassuring and serves as a model for interpreting the present situation. For N. Sukrić, writing in Muslimanski glas on 20 March, the Battle of Badr sends 'an important message to all who fight on the road of truth, justice and freedom'; it has remained in people's memories to 'feed and strengthen the religious spirit of Muslims, especially when they feel threatened or isolated, lest they become discouraged and lose hope in the immeasurable grace and help of Allāh'; finally it shows that 'one arrives at victory through a sincerely held faith, sacrifice without counting the cost, a great sabr, discipline, and co-ordination based on mutual agreement, mushāwara [consultation], and wise direction'. As for Muallim, it stresses that the Battle of Badr

has shown Muslims what it means when they regularize their relations with Allāh, when they know what they want, when they have a clear idea of their goal, and when they choose the just means to achieve it. The enemy's superiority means little; victory is certain and is brought about through a sincere relationship with the Wise and Omnipotent Creator.

\section{Islam as a Way, Islam as a Force}

Participating in the mukabela organized at the Tabački mesdžid in Sarajevo, Džemaludin Latić, chief editor of Muslimanski glas, reminded the faithful assembled there that in the time of Muhammad,

there arose fasād, confusion and disorder upon land and sea. This happened just after the Hijra and the Battle of Badr. This was the time when this aya [verse] was revealed, and things are exactly the same today, brothers and sisters; the land and the sea are in tumult. Wherever one turns, mankind lacks peace. Two major systems, capitalism and socialism, which have been enemies, are falling apart. Capitalism is triumphant, although some people forecast its near collapse, because the society created by capitalism has inherent weaknesses. Socialism is already collapsing, it has collapsed, and now major upheavals are approaching, storms on land and sea; the number of criminals is growing, people no longer know where they stand; there is confusion, wars and assassinations; people put their trust in myths, in the land, in territory, in force and in armies.

This emphasis on the crucial nature of the present age and on the omnipotence of Allāh in this situation is a feature of all the talks given at Sarajevo. But where are the Muslims of Bosnia-Herzegovina in all this, caught in the middle of the storm? After 45 years of communism, Muhammed Porča says:

We are not at all ashamed of Islam, of the Qur'ān, of the Sunna [tradition]. On the contrary, we are proud of them. The only thing is, we cannot share in this pride when we look at ourselves; we are Muslims, and if someone says to us: 'Is it Islam that tells you to act as you do? What are we going to answer then? We will be ashamed of being Muslims then. 
If the Islamska zajednica likes to put itself forward as the first victim of communist regime, as do the other religious communities, some of its members do not forget that its attitude at the time was not above criticism. M. Porča reminds us of the "particular character of this post-communist period, which is our own. It is easy to talk today of what is past, of how people were harassed, but at the time only very few people spoke out and suffered the test of fire.' Speaking of the lack of mosques in the new districts of Sarajevo and other cities in Bosnia-Herzegovina, Husein Smajić states that

somebody is certainly responsible for this, but we cannot, however, say that 'somebody' is responsible, and that we, the Muslims, are not responsible. This is not the case. We Muslims, also, voted for them [the communists], and they attacked our basic fundamentals. Consequently, you can be sure that we, also, will bear a large part of the responsibility before Allāh on the qiyāma [the day of judgment] for what has happened.

This self-criticism, which is rare enough in present-day Yugoslavia to be commented on, is not limited to behaviour in the past. It is directed also, and especially, at the weakness of the religious feelings and religious practice of Muslims. Admittedly, the growth of religious observance is evident in several respects. According to Ferid Dautović,

There are today a large number of people who, after this period of communism, this period of unbelief, of tortures inflicted upon Muslims and on the finest sons of our nation, turn back to their faith, some more quickly than others. This varies from district to district, but it is clear that ideas are changing and that within their consciences people's ideas and thoughts about the faith are changing.

It is nonetheless true that among the majority of Muslims knowledge of Islam as well as respect for its teachings remain sketchy. More examples were given during the sermons. 'Look', says Jusuf Ramić, 'we've got things the wrong way round. We perform the hajj [pilgrimage to Mecca] thirteen or even seventeen times, but we don't pay zakāt, even though zakāt comes before hajj. I don't know what this means, but something isn't right'. In similar vein, M. Porča thinks that if they don't know the Qur'ān: 'the Muslims of today have no excuse. They have been taught, they cannot say, "I haven't had a chance to learn." (...) Allāh knows how much time we spend in front of television, in reading newspapers and other things, in conversation, in cafés, in tea rooms, and how much time with the Book of Allāh'.

M. Porča's remark is interesting, because it shows that as well as referring to the authoritarian imposition of atheism by the communist regime, some members of the Islamska zajednica are aware that the half-hearted religious observance by Muslims is also the result of the secularization which is common to all European societies. Thus, when Husein Smajić says that 'for some people who are attacking the faith, the simplest method is to concern oneself with people's material condition', he is speaking less of material sanctions than the opposite: 'In order to detach a man from the mosque, from the church, from his faith, give him a good salary! Give him a good job! Give him a nice flat, comfort, possessions, and then look at the man who yesterday was regular in the practice of his religion. He has vanished from the mosque!' Similarly, certain sermons discuss the categories of people who are most 
affected by secularization. Two groups emerge: people living in towns, and especially in the suburbs (they are particularly mentioned by Husein Smajić), and the intellectuals, about whom Džemaludin Latić says: 'Look and see how many of them fast! And they are supposed to be the intelligentsia? They are not our intelligentsia!'

If the overall emphasis of the various talks is on weakness in religious observance and the need to strengthen it, the view of the speakers is that lack of faith is at the root of our present evils. According to Muhamed Porča, 'when people realize that they will have to answer for their actions, then they do not attack others with bombs, then they do not kill other people, then they do not do what Allāh has forbidden. They know that Allāh will question them about this, that they will have to answer for this on the Day of Judgment!'

What, then should be the attitude of Muslims in a country on the verge of civil war? Like the Muslim press, the sermons waver between sabr and jihäd; and the definitions of these are themselves a subject of discussion. Mesud Hafizovic comes back to the real meaning of the term jihād.

Islam's enemies liken jihōd or identify it with a holy war. In practice, jihād implies armed struggle in order to bring about justice, truth, rights and freedoms, but jihād implies also, in truth, a whole range of good actions. We would say of a worker, who is a worker, that he is a true fighter. One must understand jihād and mujāhid in this sense to know that they express the idea of struggle in the broadest sense (...) In another hadīth [an example drawn from the life of Muhammad], it is written that care for the poor, for widows, for the weak, is a 'struggle' along God's path. Jihäd implies involvement on the path towards truth, justice and goodness'.

For M. Hafizović, jihād is not necessarily war, but sabr, as defined by Džemaludin Latić, is not necessarily pacific: 'It does not mean only passivity, passive observation. It refers to the person who is persistent, who perseveres in his efforts. Allāh will reward this man, and if Muslims are like this, he will reward them, too. Just think for how many years, more than a decade, our brothers have suffered in Afghanistan'.

This gives rise to a two-fold warning. On the one hand, Muslims should not respond to provocation, should not provoke warfare, for, in the words of Enes Karić,

God pursues nations; if after four of five thousand years a nation does not fulfil the function which God has assigned to it on earth, this nation will disappear (...) Do good, as God does good. Do good to others, as God does good to you. Do not create disorder upon earth. Today, if we so wish, we are able to create disorder. Do you know how many people there are today under arms in Bosnia? It is said that there are 500,000 or more. Now you can go outside and shoot. That's disorder, isn't it? Do not create disorder upon earth. Allāh, God, does not love those who create disorder upon earth. I will finish with these words: the great Muslim masters have said: 'God tolerates unbelief upon earth. If someone says, 'I do not believe', God permits that. But He does not tolerate violence.' He does not tolerate disorder upon earth. When you are at home, you can take down your translation of the Qur'ān and look at Sürat al-Qisās. See just how many nations are mentioned there; nations which have 
existed and then disappeared; which have created disorder and then disappeared. Yes, disappeared!

On the other hand, however, some speakers emphasize the need for military preparations. Ismet Spahić, in particular, comes back to this subject several times:

Today, we must draw up our ranks as closely as possible, not, and I always stress this, so that we can become criminals (...), but so that we can say to anybody who advances against us, 'Do not come any closer, for here there are ranks of mu'mins [believers] who will die on these ramparts, but who will not give up their khanjar [daggers].' And we say, 'We will die, singing, for if we die in the name of Allāh, we will go to janna [Paradise]. (...) We should be careful. We are always careless. We all think, 'That won't happen!', but see how things turn out. We come back from a janāza [burial], and under our very eyes five or six of them take away fifty revolvers. (...) Nowadays, you should say your prayers at a funeral with your Kalashnikov, so that it bows and prostrates itself at the same time as you do. We must no longer live without taking due care, my brothers, otherwise they will come back, as they did yesterday to the Europa Hotel, when two people were shot in the head. Take care! Where the umma [the community of the faithful] is concerned, each person watches over the others, because I must watch over you, and you must watch over me. Take care, my brothers, especially since we live in an age when each of us needs the other; let us care for each other, and if we remain united, God's help will be with us.

Throughout all these different sermons, the faithful who are gathered together are reminded that today as in the past the solutions to Muslims' problems are to be found in the Qur'ān. In commenting on this, Dž. Latić wants first of all to show believers that 'when you read and learn the Qur'ān, it is as if it had been revealed to you (...), you will see that it literally speaks about you, you will find it ayyas, situations and messages that are directed to you personally'. 'The best teacher', Husein Smajić tells us, 'is the revelation of Muhammad' because 'history and life really do repeat themselves'.

By returning to the Qur'ān and its teachings, Muslims will find their salvation. Muhamed Porča, taking up a theme which is familiar throughout the whole of the Muslim world, asks, 'Why are Muslims backward today? Is it because they cling to the Qur'ān? No, it is because they have neglected the Qur'ān. This is why they are backward. And it is true that they are backward. So long as they fail to return to the pure principles of Islam, there will never be any progress for Muslims'.

For Muslims of every time and place, Islam is the path of salvation, both individual and collective. For the Muslims of Bosnia, it is even more the force around which they should gather. Faced with disturbances and external aggression, the umma represents both a refuge and a force. 'The umma,' says Ismet Spahić, 'is mighty. It has its own means of defence. Why am I safer with the umma than on my own? Because the Prophet said, "Nobody among you is a believer unless he desires for this brother what he desires for himself". 
For Ismet Spahić, Muslims' future depends in the last resort on their practising their religion:

According to a hadith, the Prophet said, 'The time will come when other nations will attack you, like starving people attacking stores of food'. The Prophet also said, 'Will you be few in numbers then? No, you will be many, but you will be weak'. How will you be weak? You will lead this earthly life, and you will hate death. This is a weakness which dominates you. The man whose thoughts are turned towards this world and the dunjaluk [life in this world], can never attain unto the truth. Since the Prophet speaks to us of our unity and our community, he says: 'The community which turns towards Allāh and towards the mu'mins, is strong and will conquer'. Look at history; we have suffered terrible calamities, we have lost on the physical level, we have suffered defeat in war. For a while there was not a single independent country which could be called an independent Muslim country. They were all occupied by others. However, if you look at the facts more closely, you will see that Islam has never declined. Even at that time it continued to spread. Not even then did it decline, as is alleged. Genghis Khan could destroy Baghdad, and he did so. But Islam destroyed him, and he fell to his knees in prayer and accepted Islam. The community which turn its face towards Allāh, towards the Prophet, towards the believers, this is the one which will triumph. It will survive. Remember, my brothers, one can never destroy this community.

Finally, as Džemaludin Latić reminds us,

all power is of Allāh, all power belongs to Allāh. He gives power to whom he will, and withdraws it from whom he will. (...) Allāh will gladden the heart of believers, and you can see that He alters situations in favour of Muslims, provided they persevere. How many times have small numbers of troops triumphed over mighty and more numerous troops, with God's help, because Allāh is on the side of those who endure! (...) Look for how many years, at least a decade, our brothers in Afghanistan suffered. One day this criminal Najibullah will resign. Nobody, not even he, foresaw that this international support, this mighty Red Army would collapse like a house of cards. Today it is not so much the Soviets, the Russian or Ukrainian nations, which fear Afghanistan, as Kazakhstan and the other states in that region, because they fear an Islamic power, a new type of society. Look also at how Allāh has brought this about, how they have endure, so that today they can, God willing, live out this al-fath, their liberation (...) The final decision is Allāh's. It is important that we walk in His path. He helps those whom He will, those who deserve His help, He is powerful, $\mathrm{He}$ is merciful, He comforts. If God so wills, and if we deserve it, he will comfort us in this present difficult situation. He will comfort us, because He is al-rahim [merciful]. If we endure these trials, He will comfort us. He will relieve those who endure, those who are sincere, who seek after truth and justice, who do not rob others of their territory, those who do not commit crimes and will not do so in any circumstances, who persist in their search for the good, who are open. (...) This is the promise given by Allāh, for Allāh does not change; when He promises something, $\mathrm{He}$ does not change. Most people, however, do not know this, they do not see it. Nowadays, when you speak to them, they think that power lies in with armies, 
with force, with armaments. However, our strength lies above all in this idea, this is our strength. Whoever puts his trust solely in force, in hegemony, will lose one day; Allāh will lead this force into a dead end, where it will be destroyed, possibly by itself.

If faith provides the only road to salvation, both for the individual and for the community, it is this same faith that provides the cement which binds this community together. Džemaludin Latić warns: 'Anyone who relies on his nationality, his origins, his social prestige, is living on a spider's web. His house is as weak as it can be, and Allāh will cause rain to fall upon him in his world. If our community has faith in the foundation of tawhid (monotheism), then this community will have a future, a future which Allāh will bless, and to which he will grant salvation'. In the same spirit, Ismet Spahić likens believing Muslims to tiles on a roof, where each one is supported by another.

We should all support each other in this way; we should all develop this kind of awareness of each other, and this will bear fruit. If we quarrel among ourselves, if we are divided, then we count for nothing. The Prophet said, 'The man who does not obey Allāh, does not belong to me; the man who causes conflict within my community, who leaves the jama' ' $a$ does not belong to me.' Conflict is a very serious thing, my brothers. This is why the Prophet, when speaking of relations between one Muslim and another, took a building as an example; if you start to take away one tile after another from a building, you will end up with no building. It will be destroyed; it will collapse, particularly if it is exposed to the wind, as yours and mine is in Europe. We are all exposed to a strong wind blowing from all directions. If one tile is removed, a strong wind can lift off the whole roof; we must plug every crack in our building, so that it continues to stand here

\section{Which Pluralism within Bosnian Islam?}

The re-affirmation of Islam on the part of all the speakers is in no way unexpected, and we learn little about the nature of Islam in Bosnia-Herzegovina or the various forms it takes. That being so, it is worthwhile to try to disentangle from the subjects and pre-occupations which are common to the various sermons those approaches and ideas in which they differ. Thus, both M. Hafizović and M. Porča remind the faithful that faith does not remove material misfortune; however, in spite of sharing this idea, they have very different ways of approaching it. 'It is the most difficult situations', said Muhamed Porča, 'that show who are the true believers', because,

under the threat of war people are immediately divided into three groups: unbelievers, believers, and munäfiqūns (hypocrites). Eventually, only believers will be saved. And what do believers say in these difficult times? They say: 'We belong to Allāh, and we turn to Him'. What do these words, 'We turn to Allāh', mean? They mean that the believer, the mu'min, can lose nothing in this world. If his family is killed, if he loses his goods, all of them, and even if he is killed himself, what has he lost? He alone has gained äkhira [the hereafter], he alone has gained janna [Paradise]. In this world, in this passing trial, the mu'min can lose nothing. It doesn't mater what he undergoes, 
what misfortune strikes him, because, in spite of everything, he has won through, because he is mu'min.

Mesud Hafizović calls upon us not to replace our faith

by building in this earthly world two or three country houses, because, see what will happen to them. You have heard people say, 'I invested everything that I had in this country house, then somebody blew it up, and it disappeared.' Invest, dear brother and sister, in yourself! Invest in building up yourself!

Apart from these differences in tone and sensibility, what are the differences which most concern our subject? Without any doubt, the first is the difference to be drawn between an 'open' reforming Islam and a 'closed' conservative Islam. In the past, the swing between these two has been especially pronounced in Bosnia-Herzegovina. In the nineteenth century, opposition to the reforms (tanzimāt) carried out in the Ottoman Empire was very strong in Bosnia-Herzegovina, partly because they threatened the privileges of the local oligarchies, in the administration and in the army, and partly because they raised the question of the relations between Muslim and non-Muslim populations of the Empire. This conservative reflex was to be seen again later in the form of virulent hostility to the reforms of Kemal Atatürk, a hostility which has far from disappeared today. However, from the time of the occupation of Bosnia-Herzegovina by the Austro-Hungarian Empire from 1878 onwards, and its annexation in 1908, the desire to adapt Islam to a predominantly non-Islamic political and cultural environment has gradually come to predominate. As a result, the reformist movement has come to be the dominating influence within Islam in Bosnia. One must mention in particular the influence of Muhammad Abduh of Egypt on several generations of imāms and religious leaders. The main personality of this reformist Islam was in the inter-war period the Reisu-l-ulema Džemaludin ef. Čausević, in opposition to the more conservative trend in the Association of 'ulamās of the same period, el-Hidaje.

This is the opposition which M. Hadžić, secretary of the association of 'ulamās which is hostile to the official association, and which has thought it good to take on the name, el-Hidaje, refers to when he states that

we are under the influence of a Western concept of the world and of life, of a false concept of democracy. Because of this, we have moved away from the rules laid down in the Qur'ān; many Muslims are persuaded by statements that all this belongs to the past, to the Middle Ages, to a dark age, that the Qur'ān is no longer relevant to the present day in what it prescribes, that it survives only as a moral code, that the Shari'a [Islamic law] is 1200 years behind the times, that it has not evolved, etc. Unfortunately, with such ideas and thoughts, and by saying such things, Muslims can desert their ìmān [faith]. They must demonstrate their tawba, their repentance, and turn back towards Allāh in order to become Muslims once more.

By calling for 'an Islamic humanism' at the opening ceremony of the ramazanski bajram, and by reminding his audience that Islam 'seeks the establishment of the general good, the protection of universal values, such as faith, life, reason, honour and property, which must be maintained everywhere and at all times, the Reisu-l-ulema 
Jakub ef. Selimoski placed himself firmly in the stream of 'open' Islam, which was promoted by some of his predecessors. However, at the grassroots the situation is less clear. Speaking of the Qur'ān and the way to understand it, Jusuf Ramić states that

I cannot understand the Qur'ān and its āyas unless I go back to the period when the Qur'ān was revealed, unless I go back to the pre-Islamic period, and unless I take into consideration that society, the language as it was then used, the meaning of the words, both what they mean now, and what they meant then. (...) In order to understand the text of the Qur'ān, we must go back to the time when it was revealed, in order to see, not only what was the meaning of the words at that time, but also to take into consideration everything about that society, that culture, and that way of life. Only then should we turn to the Qur'ān, because this is the only way that we can grasp it and understand it, and we must never look at the past from a contemporary perspective.

Taking the opposite view, M. Porča states that 'throughout the 23 years of its revelation, during differing periods, when Muslims were being massacred, when they were hunted down, or when they had their own state, from beginning to end, the Qur'ān remains the same'. Mehmedalija Hadžić goes on to say,

What Adam felt, what his sons felt, what Noah felt, what his descendants and also the peoples who were before his generation felt, these feelings are similar to, or even identical with, the feelings of people today and of people yet to come. This is why the Qur'ān insists that we learn lessons from those nations which have disappeared, because from this point of view nothing in us has altered.

Likewise, Enes Karić stresses the similarities between the different world religions, turning for support for this view to Mircea Eliade: 'Mircea Eliade, who has worked for many years in Paris, has produced with his fellow-writers an encyclopaedia of religion. All the world religions lay emphasis on certain constant features of mankind, several criteria of humanity, which one must possess in order to be a person'. Mehmedalija Hadžić, for his part, prefers to emphasize those things which differentiate Islam from other religions:

The difference between the Shar'̄'a which Allāh has revealed in the Qur'ān, and the teachings of other religions, is that in the other religions the highest ecclesiastical organs have the power to abolish certain laws and rules, etc. This cannot happen in Islam. Nobody has this prerogative, nobody has the right to abolish anything that Allāh has decreed, or to decree anything that Allāh has not laid down. Thus, nobody in Islam has the right to forbid anything which is $h a l a \bar{l}$, i. e. that is authorized, nor to authorize anything that is harām, i.e. that is forbidden.

Though it is necessary to set this 'open' reforming Islam against 'closed' conservative Islam, in order to understand the forces at work within Bosnian Islam, this is not the only relevant factor. In fact, the evolution of world Islam over several decades already, as well as the recent collapse of communism in Eastern Europe, makes the question of the relations between Islam and politics particularly topical. Now it would be a very serious mistake to identify reforming Islam with non-political 
Islam, and conservative Islam with political Islam (or the other way round). In the particular case of Bosnia-Herzegovina, several facts tend to prove that these two oppositions do not coincide. For example, the Islam of the rural areas, with which many imāms are connected, is much more conservative but less political that Islam in the towns. Salih Čolaković, President of the Islamska zajednica for BosniaHerzegovina, seems to depend on this rural Islam and its dense network of $i m \bar{a} m \mathrm{~s}$, in his opposition to certain leaders of the SDA. At the same time, a fair number of the young intellectuals coming from the religious schools and with links to the SDA not only support the politicization of Bosnian Islam and its structures, but at the same time enthusiastically defend the revival of $i j t i h \bar{a} d$ (individual efforts at interpretation) in the face of the conservatism of certain religious leaders.

The difference is striking, for example, between Mesud Hafizović, with his insistence upon the individual, internal nature of the Islamic faith, and Džemaludin Latić, with his stress on its communal character. For Mesud Hafizović, in fact, ìmān (faith) is above everything else a personal relation with God, from which everything else flows:

One must build up one's ìmān, develop one's ìmān, enrich one's ìmān, perfect one's imman. It is precisely in response to this that we have the $\bar{a} y a$ in the Qur'ān which says that the true believers are those who believe truly in Allāh and his Prophet, who do not doubt for a single instant, who struggle on the path of God with all their possessions, their lives, in other words, with everything at their disposal (...) Referring to the true qualities of believers, it is stated elsewhere, 'The true believers are those who tremble when the name of Allāh is mentioned', or when the ayyas of the Qur'ān are learned, and the $\bar{\imath} m \bar{a} n$ reinforces and when the faithful become firmer in their faith, firmer in saying these words, 'lā ilahā illā-llāh' [There is no God but God]. (...) This word $\bar{i} m \bar{a} n$, thus has a universal meaning: humanity, humanism, good works, preservation from sin. In order words, it presupposes intimacy with God, and if you are intimate with God, then you become intimate with your own soul, and then with your family, and your neighbourhood, and the society in which you live, and ultimately with the whole cosmos in its entirety.

For Džemaludin Latić, on the other hand, to be a believer (mu'min) does not mean by itself to be a Muslim.

Let me explain the difference between Muslim and $m u$ 'min. It is the difference between the grain and the ear. Many people consider that they are mu'mins, that they believe in God, but they do not obey Him absolutely, they do not follow His precepts. Thus Muslim (the one who submits to God) represents a higher degree, when, beside this faith in your heart and in your thoughts, you go beyond this, you merge into the ear.

Placing even more emphasis on the collective character of Islam, Ismet Spahic has no hesitation in saying, "The Prophet says, "None of you is a believer, if he does not desire for his brother what he desires for himself." What I desire for myself, I should desire for you. If I do not have this in my soul, I am not a believer. The fact that we perform namaz [prayer] and fasting is only a formality.' 
This opposition between an individualized Islam, stripped of its political dimension, and an Islam, whose collective dimension, as well as its social and political meaning, are given prominence, can also be seen in the two sermons dealing with the payment of zakāt and of sadaqat al-fitr delivered by Mesud Hafizović and Mustafa Spahić, respectively. For Mesud Hafizović, zakāt is based on the universal principle of helping and sharing:

Everything has its zakāt. Zakāt of the body is fasting; zakāt of science is to spread knowledge abroad; zakāt of one's house is the room kept for friends. And let us not only build two or three houses. Who knows whether our grandchildren will have need for them? We neglect the development of ourselves as individuals, we abandon our nearest, our neighbours, our society. Look at the situation in which we find ourselves today, where some people have virtually nothing to eat. That is why I appeal to you to help as much as you can, whether it be through Merhamet or through some other charity organization, or whether it be through the various funds which you read about daily in Oslobođenje $\left[{ }^{9}\right]$, in Muslimanski glas, or in Preporod. Only in this way can you protect your family from misfortune and distress.

Mustafa Spahić also reminds his hearers that 'just as you purify, preserve and assure your goods with zakât, you guarantee your lives with sadaqat al-fitr. In this way you have complete assurance, both for people and goods.' His purpose, however, is also to remind people that 'ever since the times of Ibn Khaldun, Aristotle, Hobbes and John Locke, two of the major functions of the state have been to guarantee the lives and property of people'. Here are the words of Mustafa Spahic starting with a socio-political interpretation of zakāt and sadaqat al-fitr which goes straight to the point:

In effecting the distribution of zakàt, sadaqat al-fitr, and the usual sadaqat [alms], thoroughly and logically, avoiding charlatans, we establish a kind of social justice and balance between people; we reduce the economic and social differences, which set on one side the comfortably-off and rich, and on the other side wretchedness and utter poverty. If these circumstances persist, they can only lead to a social explosion, a revolt, and a radical social revolution. (...) Neither zakāt, sadaqat al-fitr, nor sadaqa, be it at the state level or between individual Muslims, even from the time of the first four Caliphs, have ever really been put into full operation, because it has always been those who own most property who have fixed the amount of $z a k \bar{a} t$ and sadaqat al-fitr and then collected it. However, people have never completely given up this idea, and it is thanks to zakatt, sadaqat al-fitr and sadaqa, as well as to the conscience and initiative of the people, that, in spite of all the misery and poverty, Muslim people have never known a radical communist class revolution.

While keeping in mind as relevant the contrasting positions found in Bosnian Islam, i.e. the two oppositions between reforming and conservative Islam, and between political and non-political Islam, it is possible to distinguish four approaches, or currents of opinion, within the Islam of Bosnia-Herzegovina:

\footnotetext{
${ }^{9}$ Oslobodenje is the principal daily newspaper of Bosnia-Herzegovina.
} 


\begin{tabular}{|l|c|c|}
\hline & Reforming Islam & Conservative Islam \\
\hline Non-political Islam & Secularized Islam & Traditional Islam \\
\hline Political Islam & Political Islam & Islamism \\
\hline
\end{tabular}

Over and above these terms, which must be further discussed and possibly modified, it would seem that the variations within Bosnian Islam are the same as those which run through the whole of the Islamic world. This typology broadly corresponds with the typology established for the whole Muslim world by Fikret Karčić, professor in the Faculty of Islamic Theology in Sarajevo. He distinguishes four legal, and so by implication, ideological, currents of thoughts in contemporary Islam:

\section{Secularists}

For them Islam is a religion in the commonly accepted meaning of the word, whose legitimate sphere is the personal, private one of the individual. They emphasize the moral values of Islam, but no longer regard its teaching as being the basis of the social, political and legal system.

\section{Traditionalists}

Traditionalism represents a tendency, according to which Islam is defined as 'religion and law', but which accepts historical modifications of its social function, as well as of the area in which Islamic law is valid. The distinction which has occurred in history between religious and secular standards and institutions is accepted, as well as effective precedence of secular institutions. The majority of 'ulama $\bar{s}$, who provide the foundation of traditionalism within Sunn̄i Muslim countries, seek to ensure Islam's status as the state religion or the religion of the head of state, respect for religious customs and symbols, as well as the validity of the Shari' $\mathrm{a}$ a in questions affecting the personal status of Muslims, as constituting a sufficient guarantee for the revelation of Islam.

\section{Islamic Modernists}

Islamic modernism represents an ideological orientation characterized by a definite and conscious effort to re-formulate, within the framework of modern thoughts, Islamic values and principles, or the integration of modern thought and contemporary institutions into Islam. Modernists think that in this way a 'reformulated' Islamic education can provide an ideological foundation which is appropriate for public life in Muslim countries, and that a 'reformulated' Sharí' a can become the basis or an important element of a system of positive law.

\section{Revivalists or Radical Islamists}

These represent that ideological orientation in the contemporary Muslim world which strives to develop a complete ideology on the basis of the principal sources of Islamic teaching and the early history of Islam. They emphasize that Islam encompasses every 
aspect of life, and is most frequently defined as a system. The authenticity and specificity of Islamic standards and institutions is stressed (...) They regard the experiences of the early Muslim community of Medina as providing a norm for behaviour, taking them as a model for action, and not just as an historic example of the fulfilment of Islam. This is why Islam is defined as 'religion and state', and why their efforts are chiefly directed towards creating the conditions for establishing this sort of order. ${ }^{10}$

If the information so far considered makes it possible to indicate the pluralism within Bosnian Islam, together with its structures and its similarities to the Islam of the entire Muslim world, it is, however, too fragmented for it to be possible to assign individuals, let alone institutions, an exact place within this pluralism. The most one can do is to underline to what extent this pluralism is reflected in several of the debates which have disturbed the Muslim community of Bosnia-Herzegovina, whether openly or beneath the surface: for example, the argument between the supporters of courses of religious instruction for each community and the supporters of courses in religious culture common to all, matches the opposition between 'closed' and 'open' Islam. At the same time, one can state that, equally opposed to the religious hierarchy which represents a traditional and rural Islam, the members of the Association of 'ulamās el-Hidaje, which is definitely the real focus of Islamism in Bosnia-Herzegovina (if such a thing really exists), and the political leaders of the SDA increasingly come together on a practical basis, if not on grounds of affinity. However, is it not a fact that the active rural Muslims are those who voted most overwhelmingly for the SDA? It is not also a fact that the editorial team of Muslimanski glas is largely made up of young intellectual Muslims who were dismissed from the staff of Preporod in March 1991, because of their activities on behalf of the SDA, but also because of their habit of publishing in the religious press articles which were considered to be unorthodox from the Islamic point of view?

To identify exactly the various currents and their supporters, to analyse the relations between them and the synergy which links one with another, would need considerably more work, and, in any case, a situation less characterized by setbacks, ambiguities and continual chaos. Lacking this, it remains to enquire how Bosnian Islam reflects and impinges upon the crisis of inter-ethnic relations, which at the time of Ramadān was about to plunge this republic into civil war and horror.

\section{Bosnian Islam Faced with Civil War}

As has already been pointed out, all the sermons that were given bear the mark of the political and inter-ethnic crisis in which Bosnia-Herzegovina was plunged at that time. Against this background, the influence of Islam on the way this crisis was handled by the Muslims of Bosnia-Herzegovina, is interesting from several aspects: What is the attitude of Bosnian Islam towards a crisis characterized by exasperated nationalisms, when Islam is supposed to ignore the idea of the nation (preferring that of the umma, the community of believers)? Is there just one or are there several strategies for the re-Islamization of the Muslim population, and how can they be applied within the context of crisis? Can one find in these sermons elements for

\footnotetext{
${ }^{10}$ These definitions are from F. Karčić, « Šeriat u savremenom muslimanskom svijetu », in: E. Karić (ed.), Suvremena ideološka tumačenja kur'ana i islama (1990).
} 
understanding the Muslim strategy for dealing with the political and inter-ethnic crisis in Bosnia-Herzegovina?

On the subject of the relations between Islam and nationalism, the Reisu-l-ulema Jakub ef. Selimoski had stated at the opening ceremony of the ramazanski bajram, on 4 April, that 'any advancement of one nation above the others, with the goal of domination and subjection, is alien to Islam, because the Qur'ān teaches us that we are only divided into nations and tribes into order that we may get to know each other better'. But what repercussions did this message have in the various mosques in Sarajevo? By looking more closely at the various statements made about the umma and about relations with other national and religious communities, it is possible to discover to what extent this discussion on the subject of nations leads in BosniaHerzegovina to an attitude of 'ecumenical' reconciliation, or to an attitude of 'panIslamic' exclusion.

Obviously, the clash between these two attitudes is not unconnected with the clash between 'open' and 'closed' Islam, and it is not surprising to find the same individuals taking up similar positions on this subject. Thus, whereas Mesud Hafizović calls upon believers not to replace 'our representation of God, this absolute value, with others, with the idea of nationhood, which is what is happening at the present time', Ismet Spahić repeats to his audience,

Our community, the Muslims, constitutes the umma. This is not the qawm, this is not the nation. This is the umma, and umma implies something united, possessing a common conscience, a collective conscience, a collective life, so to speak, and where people feel for others what they feel for themselves. It is not surprising that when colonizers in the parts of the world inhabited by Muslims, realised that the time had come for them to quit, they imposed the idea of qawm on these regions. If you have ever had access to a book printed in Arabic and you have opened it, it always begins with these words: 'Oh, Arab Nation!' There is no nation; among us the umma is united. For the Prophet said: 'The Arab has no advantage over the non-Arab, neither has the non-Arab over the Arab'. You are all the sons of Adam, and Adam was made out of earth, you are all brothers, because the only difference between you is dīn [faith] and good deeds. (...) He does not divide people into Arabs, French, Americans, Bosnians, Serbs or Croats, because all come from the same stem and have the same roots. He merely says, 'You differ from each other only in faith, and faith must be manifest in good works'.

In the same spirit, Džemaludin Latić refers to an āya revealed by Allāh:

'in order that Muslims know and uphold the idea of tawhid [monotheism], the idea of the one and only God, they should range themselves on His side, for this is how Allāh has created the world'. This idea of tawhīd, which is most strictly and correctly held among us, is opposed to the idea of shirk [polytheism]. A hadith states: 'He who dies under a national flag, for a tribe, or for any nation, and not for the idea of tawhid, not for the idea of God, has died in shirk, like a mushrik [idolater]'. Muslims don't understand this. When we speak of nations, we are speaking of the Islamic umma, and thus of that which links us with our brothers in Kosovo, in Bulgaria, in Kazakhstan, in 
Slovenia, in Germany and everywhere. We are not linked by language or anything else, but by the idea of tawhid, the idea of the only God, and by good deeds. This is what is so marvellous. This is what links us together. This is what we stress. 'Alī ibn Ab̄i Tālib, the Just [the fourth Caliph], said: 'Every nation has its own qibla [direction of prayer], its line of conduct, its system of values, and you challenge them, because your qibla is the Ka'ba'.

If, then, the umma is usually promoted to the detriment of the nation, it becomes the standard by which relations between Muslims and others are defined. Džemaludin Latić devotes quite a long passage of his contribution to this question:

Anybody who believes in one God and performs good deeds, anybody who believes in life after death and in the Day of Judgement is ahl al-kitāb [one of the People of the Book], and one can hold a nice discussion with him. But there can be no discussion with one who commits crimes, who practises zulm [injustice]. This is a rule for us in these present times: there can be no discussion or dialogue with those who commit crimes against Muslims or against anybody else. Say to them: 'We believe in what has been revealed to you, because we believe in all the kutubs [books], and in all their suhufs [pages], in what has been revealed to you, as in what has been revealed to us.' And say to them that our God is also your only God, because there can only be one God who has created everything, who is ilāh al-nās, the God of all. But you may say: 'We are the Muslims'. However, this should be translated into, 'We are those who submit to God, the only God, and who obey Him'. We do not attach ourselves to a single prophet. In this we differ from Christianity, because Christianity does not recognize that Mohammad is khātim al-anbiyā [the Seal of the Prophets], the prophet who subsumes in himself all the other prophets. We have rejected the catastrophic idea of Judaism, which would make of us a chosen race. We are chosen neither by race, nor by nationality, no by language, nor by our origins, but only according to how much we are in it $\bar{a}$ ' $a$, or obedience to God. (...) This remains, dear Islamic brothers and sisters, our permanent platform, so to speak, in all our discussions and in our actions, whenever we find ourselves, because we are surrounded, and we live amidst Christians and Jews. This is our eternal message.

Apart from these general reflexions on the conduct of relations between Muslims and the other People of the Book, other religious communities are generally presented as a threat, actual or potential. After leaving the Ottoman Empire in 1878, the whole of the cultural, political and social life of the Muslims in Bosnia-Herzegovina was characterized by the desire to survive in a new context, which was seen as one of encirclement by hostile states and people. This feeling of being encircled has grown strongly; just as Ismet Spahić feels that 'here in Europe we are subject to strong winds, blowing from all directions', Džemaludin Latić invites his audience to look at

What is happening in the Balkans; how Muslims see themselves encircled, how they are subject to pressures, first of all a few years ago in Bulgaria, then in Macedonia, in Albania, in Kosovo, our brothers in the Sandžak, and how we are in zijet [great danger] through the action of certain forces which claim 
that certain lands are historically theirs, and do not allow, for example, emigrants to return from Turkey, etc.

Among some participants, this feeling of being threatened develops into the wish to isolate the Muslim community from other communities. This is particularly striking in the words of Ismet Spahić, who says,

Oh believers! You should not take the Christians and Jews to be your protectors, because they protect each other. They do not recognize you Muslims as believers, because Christianity has never recognized Islam as a revealed religion. As far as they are concerned, we are pagans, a non-revealed religion. The Muslim cannot turn in this direction and seek protection; he should turn towards his brother. The man who turns aside from you and looks for protection and friendship from them, belongs to them.

This desire to keep the different communities separate, to carry inter-ethnic hostility over into private, everyday life, is seen in the opposition to mixed marriages. Muhammed Porča, Mehmedalija Haždić and Džemaludin Latić remind the audience in similar terms that in conformity with the precepts of Islam, 'the Muslim man may marry a woman from the People of the Book, but a Muslim woman may not marry anyone other than a Muslim'. Džemaludin Latić speaks again of the shirk (polytheism) to be found among the Muslims of Bosnia-Herzegovina: 'Nowadays you have the situation where a Muslim hopes to marry his daughter to a non-Muslim, provided that he is as well off as he is himself, rather than give her to a Muslim who is poor, who is a countryman, or who does not have a university degree'.

The question of marriage between Muslims and non-Muslims has existed in Islam since its earliest days, and during the Austro-Hungarian occupation it was a sensitive issue. Nonetheless, this desire for the Muslim community to be separate represents a two-fold break. Firstly, it is a break with the traditional strategy of Muslim leaders, religious as well as political, who have certainly tried to preserve the cultural identity of their community, but also, and more importantly, to ensure its survival by entering into the multi-cultural society of Bosnia-Herzegovina, and by a clever play of balance and alliance with the political forces, whether Serb or Croat. Secondly, it is a break with the actual attitude of the Muslim population of Bosnia-Herzegovina, which in 1990 was the population group which showed the least desire to distance itself from the other national communities in Yugoslavia. ${ }^{11}$

It would seem, therefore, that to describe Islam and its conception of the umma as a calming influence in the crisis in inter-ethnic relations in Bosnia-Herzegovina is simplistic, to say the least, particularly when the desire for isolation goes hand in hand with an equally strong desire for the homogeneity of the own community. According to Ismet Spahić

every time that you see a majority of believers coming down on one side, remember that this represents haqq [the truth], because believers cannot gather together in dalāla [error]. God's help is on the side of the jamā' 'a. If we stay together and remain united, my brothers, God will help us. Whoever departs

${ }^{11}$ D. Pantić, Nacionalna distanca građana Jugoslavije (Beograd,1991). 
and separates himself from the jama ' $a$, from the group of the umma, will go to Hell. He cuts himself of, and goes to Hell. That is why we must consolidate our ranks, and put aside these little skirmishes which are of no importance, which belong to this world; brothers and sisters, faith should unit us, for the issue at stake is the preservation of our faith and our very being.

There is only one step between the policy of homogeneity within the own community and exclusivity, and Ismet Spahić does not hesitate to take it:

As the Qur'ān says, those who perform namaz [prayer], who give zakāt, who perform the $r u k \bar{u}^{\prime}$ ' [bowing during prayer], they are the $u m m a$. Without these, there is no umma. They can call themselves Omer, Mustafa, or Ahmed, but if there is no namaz, no zakāt, if they are not within the jamá' $a$, they do not belong to the umma. (...) This umma, which binds us together, this imān [faith] are stronger than blood. The Qur'ān says, 'Oh Noah, this son is not your son! Why is he not your son? He does harmful things, and I have said that Islam divides people according to their deeds, their works. He could not belong to Noah 'alayhi al-salām, even if 'alayhi al-salām gave him life'.

In the same spirit, Džemaludin Latić expressed himself strongly against secularized Muslim intellectuals:

Without sajda [prayer], there is no Muslim intelligentsia. They can continue to exist as they are in the biological sense, they are not the intelligentsia of this umma, of this people. We will not argue with them; they are dear to us, but they would be dearer to us if they were within the din [faith] of Islam. This umma, however, can only grow on the basis of the idea of tawhid [monotheism]. (...) There you are with your qualifications, awarded to you by an authority which you served in your glory. The fact is that you would not consider us as men, that you despise us because we fall to our knees in sajda [prayer], that you think it is retrograde to have a religious conscience, that you think it is only provincials, people from the country, who kneel down to pray, this is shirk! This is not the path that we follow. This leads to catastrophe for the nation. It is intolerable. The fact that they seek emancipation for a Muslim nation without namaz [prayer], that they act so proudly with their titles, that they think they are so important, it is all a trap set by Satan. We will never allow this, not at any price. They are more of a danger to us than the Chetniks, because if they educate future generations in this way, (...) then in 60 years we will have a nation founded on shirk.

\section{Policies for the Re-Islamization of Bosnia-Herzegovina}

To question the role of Islam in the present crisis of the inter-ethnic relations in Bosnia-Herzegovina leads one logically to put the question the other way round: what is the place of the present crisis in the possible re-Islamization of Muslims in BosniaHerzegovina? From this point of view, there is no clear evidence as to how far the desire for re-Islamization affects the desire, already discussed, to isolate the Muslim population and maintain its homogeneity, or vice versa. In any case, it seems quite clear that one of the chief disputes within the Muslim community and its institutions, both religious and secular, centres around the question of the connection between the 
worsening of inter-ethnic relations and the re-Islamization of the Muslim population. Within the Islamska zajednica the team that has gathered around Salih ef. Colakovic has apparently given priority to a policy of appeasement, a policy of compromise, allowing religious education, the restitution of waqfs, etc., which are essential for reIslamization 'from the bottom up', and which must by definition proceed step by step. Within the SDA, on the other hand, the exacerbation of inter-ethnic tension has been seen, if not as something desirable, at least as something inevitable. As a result, the 'lay' militants of this party have been tempted to use Islam to promote a policy of national homogeneity. The 'religious' ones expected that an aggravation of tension would favour the re-Islamization of a largely secularized population.

It is impossible at present to give a precise answer to questions about the various policies of re-Islamization current in Bosnia-Hercegovina, their exact nature, and the way they relate to each other. However, an analysis of the sermons that were delivered allows us to draw attention to certain aspects of these policies. One is struck, for example, by the fact that they all contained references to the beginnings of Islam, its development, and its spread during the time of Muhammad.

In this context, all the contributors insist that any future re-Islamization would have to proceed by stages. As Muhammed Porča points out, 'it is not easy to tell people everything at once, because in many cases they have got used to their present lifestyle, it is what they have been taught, and it suits them'. This is certainly why Jusuf Ramić, in reference to the ban on alcohol, says,

You know that Muslims have drunk alcohol, and that alcohol was forbidden about the sixth year of the Hijra. Up until this year, alcohol was drunk. However, the first ayya to ban alcoholic drinks, or partially ban them, came when questions were put to the Prophet about wine, occultism and gambling. They are useful and harmful, but they are more harmful than useful. This was the first $\bar{a} y a$, and when it was revealed many people gave up alcohol, but there were also some who continued to drink. Then there came the second $\bar{a} y a$. 'Do not pray in a state of drunkenness'. However, the definitive prohibition came only with the third $\bar{a} y a$, and then everybody gave up alcohol, and it was much less painful than in America when they tried to ban the consumption of alcohol by law. So you see that this did not happen overnight, but gradually. Everybody gave up alcohol, it worked by taking gradual steps.

Consumption of alcohol, the choice of given names for children, learning the Qur'ān, the five daily prayers, all the different subjects tackled, reflect the many activities involved in re-Islamization 'from the bottom up', which are seen throughout the whole world of Islam. In this type of re-Islamization, the family unit plays an essential role. Ferid Dautović recalls that:

The Prophet never ceases to say that you must educate your children in Islam, that you must educate them in three qualities: (1) to love the Prophet (and ask yourself how many of us really know the Prophet, because in order to love him, we must know him and know about his life); (2) to love his family; (3) to teach our children to get to know the Qur'ān, and to get to know it ourselves, if we have not already done so. 
For, as Muhammed Porča says,

Today Muslims have no excuse. They have been taught. They cannot say, 'I didn't have the chance to learn'. There are people one can ask, there are places where one can learn. If there is something you don't know, ask somebody who does. You don't know how to teach your children, or your grandchildren? Take them by the hand, and bring them to the hodža [imām]. The hodža isn't capable? Then take them to somebody who is.

In any case, as Hussein Smajić says, 'We are all imāms to some extent, beginning in our own households which we direct as heads of the family.'

Above all, this process of re-Islamization is understood as developing out of faith, in order to spread out into practice, from the individual into the community. On the relation between faith and practice, Ferid Dautović had this to say: 'Brothers and sisters, we must believe firmly in the äkhira [the hereafter]. All our problems arise when we doubt the äkhira and our need to answer before Allāh. (...) Those who believe firmly in the äkhira, do not enjoy the luxury of not obeying Allāh in any of his fards [obligations], any of his orders, or any of his prohibitions'. Speaking of the link between the individual and the community, Hussein Smajić remembers

The recent past, eighteen months or two years ago, when it was important to criticize anyone who went to the mosque, who fasted, who sent his children to the mekteb [qur'ānic school], and even more anybody who made a public display of his Islamic faith. I think that the time has now come to call those who have strayed from the faith to return to the rightful path; to summon those who, for whatever reason and in whatever way, have erred. (...) There is something else that I should like to say to you. We say here: ' Oh God, guide us!' 'Us' means me, my wife, my children, and all believers who have sinned; and all those who do not believe and have no desire to return to the path of righteousness. I think that in this respect the order in which we call upon people is very important. You know about Muhammad in the history of Islam. Who was the first person he addressed? Khadija. That was no accident. Next he addressed the closest members of his family. In the same way, if somebody is not on the path of righteousness, it is our duty to speak first of all to them, then to our extended family, and possibly to those of our acquaintance.

\section{A Political Revolution without a Religious Revolution?}

The progressive re-Islamization of the Muslim community is apparently a goal shared by all the different trends within Bosnian Islam, and it would be wrong to think, after all, that there could be people with a concern for their religion who do not want to promote and strengthen the religion which they serve. As for the possible political strategies of the Muslims in Bosnia-Herzegovina, it would be pointless to try to find the key to them here. All the same, we must mention several references which run like a key to them here. All the same, we must mention several references which run like a thread through the talks. Džemaludin Latić recalled how in the time of the Prophet two blocks confronted each other: the Byzantine Empire and Persia; and how the victory of the Byzantines over the Persians in 623, the victory of Christianity over paganism, was of immediate benefit to the Muslim community, which was still weak 
at that time. In the same vein, a few days after the Sarajevo agreement had been signed, Mehmedalija Hadžić recalled the Peace of Hudaybiyya which Muhammad made with the Quraysh, and saw in this a new tactic leading to eventual victory.

Most of the schemes for re-Islamization under way in post-communist BosniaHerzegovina evoke the 'Islamic Declaration' written by Alija Izetbegović, the present President of this Republic in 1970. The SDA is eager to re-publish it and to promote it. In this Declaration, Izetbegović wrote,

the Islamic renaissance cannot begin with a religious revolution, but at the same time it cannot progress or be brought about without a political revolution (...) In our case Islamic renewal means in fact the Islamization of people who call themselves Muslims, or who are called Muslims by others. The starting point for this Islamization is unshakeable faith in God, and a strict observance of religious and moral standards on the part of Muslims. Only religious renewal will be able to give the strength of character which says that the Qur'ān's prescriptions, in particular those directed against deeply-rooted social evils, or which disturb the rich and powerful, are to be applied without limit or compromise. Religious renewal will lead to their implementation without violence, without hatred, because they are understood and accepted by everybody, or at least by the majority. (...) The emphasis put on the priority of religious and moral renewal does not mean that the Islamic order can be brought about without Islamic power, and cannot be compromised in this way. It means that we do not begin by seizing power, but by winning over people, and that Islamic regeneration means first of all a complete reversal in the sphere of education, and only finally in the sphere of politics. ${ }^{12}$

Such a plan for re-Islamization 'from the bottom up' represents the common foundation for varying re-Islamization activities in Bosnia-Herzegovina since the collapse of communism. It is one of the paradoxes in the Yugoslav crisis that the most enthusiastic promoters of this plan in Bosnia-Herzegovina found themselves pushed to the head of the Muslim nation, while the evidence shows that the various attempts at Islamization are still far from having had the hoped-for results.

\section{Postscript : Two Years On}

The above article describes the atmosphere that reigned in Muslim religious circles in Sarajevo in March 1992, a few weeks before the outbreak of the war in BosniaHerzegovina. It was written in May 1992, at a time when no one yet knew that this war would reach levels of violence and horror not seen in Europe since 1945, particularly in terms of ethnic cleansing.

Since March 1992 some 250,000 people have died in the conflict, more than two million have been displaced, and hundreds of mosques have been destroyed by Serb or Croat troops. Bosnia-Herzegovina as it was before the war no longer exists. So can this text, re-published without amendments, help us to understand the BosniaHerzegovina of today? In spite of some gaps and misapprehensions, it highlights

\footnotetext{
${ }^{12}$ A. Izetbegović, Islamska deklaracija (Sarajevo, 1990).
} 
some internal developments of Bosnian Islam which have been pursued and even accelerated during the war.

The Islamic religious structures, the Islamska zajednica, have undergone profound internal changes. In April 1993, the Reisu-l-ulema, Jakub ef. Selimoski and the president of the Mešihat of Bosnia-Herzegovina, Salih ef. Colaković, were replaced by a Naibu-l-reis (Deputy Reis), Mustafa Cerić, assisted by Ismet Spahić, whose sermons we quoted extensively in May 1992. This change of direction marks a victory for the radical political trend in Bosnian Islam, represented by the el-Hidaje association and supported by the SDA, over less political trends, both progressive (J. Selimoski) and traditionalist (S. Colaković). From this point of view, the description of the pluralism of Bosnian Islam given in May 1992 has proved relevant.

Islamic religious discussion in Bosnia-Herzegovina apparently remains centred on the affirmation of Islam as a way of life and a source of power for a community under threat. Since Ramadān 1994, religious assertiveness and military mobilization have been closely linked, even within a Bosnian army that wants to be multi-ethnic and anti-fascist. The appearance within the army of 'Muslim brigades', openly claiming to be carrying on jihād, shows that the slogan of A. Izetbegović, 'believe and fight', quoted at the beginning of this article, has not gone without response.

Nevertheless, the objective set by A. Izetbegovic in 1970, 'the Islamization of the Muslims', remains remote. It is true that the SDA controls the state apparatus and many of the educational and cultural institutions, but this opens the way for reIslamization projects implemented 'from above' on a Muslim population that has remained relatively unreligious, while Izetbebović intended to support re-Islamization 'from below'. By changing the term 'Muslims' to 'Bosniaks' (Bošnjaci), and by bringing about the breakup of the Yugoslav Islamska zajednica and replacing it with a Bosnia Islamska zajednica, the SDA has sanctioned loyalty to the nation, while Izetbegovic intended to sanction loyalty to the umma. In the war, the internal contradictions of Bosnian Islam, which were latent in 1992, have been exposed to the full light of day. 